\title{
Projekt NAVIS - presentation and promotion of cultural (archeological) heritage through the construction and use of historic vessels
}

\author{
Matej Draksler, Mojca Fras, Rene Masaryk
}

Pričujoče besedilo je kratko poročilo o projektu NAVIS, s katerim želimo okrepiti zavest o arheološki dediščini; v ta namen gradimo zgodovinska plovila z uporabo orodij in tehnik, ki so kolikor mogoče blizu izvirnim.

Ključne besede: Projekt Navis, zgodovinska plovila, zgodovinska orodja, kulturna dediščina, deblak, veslanje, eksperimentalna arheologija

This paper is a report about the project NAVIS, through which we try to raise the awareness of archaeological heritage through construction of historical vessels using historically authentic tools and techniques.

Keywords: Projekt Navis, historical vessels, ancient tools, cultural heritage, logboat, paddling, experimental archaeology

I

n 2016 we have begun with the realization of the long-term project of the reconstruction of historic vessels. Each year a vessel that once sailed along the Ljubljanica River, lakes or sea, is reconstructed and presented to the public (schools, the professional and general public). Since the beginning of the project students of archaeology and other volunteers constructed two Roman logboats under the guidance of experts. The building site was opened to the public and anyone was able to observe or participate, as we encourage the visitors to join in and experience life in the past in a original way.

The practical part of project is always held in spring and summer. During autumn and winter nights we are researsching ancient vessels, developing project and connect people who are in love with experimental archaeology. In this year edition of the project in May and June, we will construct two prehistoric longboats that sailed Ljubljana's marshes in neolithical period. We will use reconstructions of stone tools from various known slovenian archaeological sites.

As mentioned above we use mostly reconstructed tools as our goal is not only to construct the vessel but also to understand, learn and use the techniques that were used in the construction of such vessels. Each construction was followed by launching of the boat on the Ljubljanica River and promotional paddling with the intention to revive the use, which was typical for such a vessel and also contribute to the revitalization of the former waterway.

The project is implementant on many levels - education, promotion and tourism. In cooperation with the Department of Archaeology, Faculty of Arts, University of Ljubljana we carrie out the practical training for 3 rd year students. In cooperation with the Museum and Galleries of Ljubljana, we present the heritage of the Ljubljanica River and the pilot project of the recently opened experience and exhibition site in Vrh- 
nika »The Ljubljanica River « to the local and general public. Our goal is also to encourage the use of archaeological heritage in the development of new tourism services so we organise and promote various events with a name Deblak je ŠPICA!

\section{Povzetek}

Skupina STIK (Arheofakt), Inštitut za podvodno arheologijo in institucija Škrateljc s še nekaj drugimi sodelujočimi od leta 2016 sodelujejo v Projektu Navis - projekt rekonstrukcije starih plovil. Cilj tega projekta je prezentirati in promovirati kulturno (arheološko) dediščino z osebno izkušnjo konstruiranja in rabe zgodovinskih plovil. Skupina skuša vsako leto sestaviti plovilo iz določenega zgodovinskega obdobja, in sicer z orodji in tehnikami, ki so kolikor mogoče blizu izvirnim. Z lastnimi izkustvi javnosti predstavljamo načine življenja iz preteklosti, javnost pa je tudi vabljena $\mathrm{k}$ sodelovanju. Vsakdo je dobrodošel pri projektu, da sodeluje pri gradnji plovil in se udeležuje delavnic, ki potekajo med procesom njihove gradnje. Ko so plovila končno nared, jih pošljemo prvo plovbo po reki, jezeru ali morju - in preteklost vnovič za trenutek postane del sodobnega življenja ...

\section{Summary}

Since 2016, the institute Skupina STIK (Arheofakt), Institute for Underwater Archaeology and institute Škrateljc with other participants, are leading a Projekt Navis - project of reconstructing old vessels. The aim of this long-term project is to present and promote cultural (archaeological) heritage through first-hand experience of constructing and use of historical vessels. Each year the team attempts to construct a vessel from a certain historical period using tools and techniques, which are high-scale copies of the ancient originals. With our own experiences we are introducing to the public the way of life in the past. Also the public is encouraged to get involved in the project itself - everyone is welcome to help building the boats and attend the many workshops and events which are being held during the time of constructions of the mentioned vessels. Finally, when the vessels are ready, we send them for their maiden voyage on the river, lake or the sea and so the past becomes part of the contemporary life... 